\title{
Analisis Kesiapan Siswi Sekolah Dasar dalam Menghadapi Menarche
}

\author{
Indah Lutfiya \\ Departemen Biostatistika dan Kependudukan \\ Fakultas Kesehatan Masyarakat Universitas Airlangga \\ Jl. Mulyorejo Kampus C Unair Surabaya 60115 \\ Alamat Korespondensi: \\ Indah Lutfiya: indahlutfiya@gmail.com
}

\begin{abstract}
Puberty among female adolescent occurred when coming to menarche period. The age of menarche among girls in Indonesia has decreased in recent years. It impacts on readiness of menarche among pre puberty female adolescent, both physically and mentally. There were many girls who stated that they didn't ready to face menarche. The unreadiness of female adolescent on experience menarche will impact to their behavior of vulva hygiene and increase the risk of being infected by sexually transmitted diseases. Surabaya is one of the cities in East Java province which the highest number of female adolescents. SDN (State Elementary School) Pacarkembang 1/192, Tambaksari District of Surabaya contributed to the most number of pre puberty female adolescent in Surabaya. The purpose of this research was to analyze factor that affect readiness of menarche among pre puberty female adolescent. Variable on this study covered parenting style, knowledge of female adolescent and number of source information. This research was an analytical research with observational method. The population in this study were Elementary Student who in grade four and five with sample number of 55 students. This study used random sampling. Analysis of data used logistic regression. The result shown that variable of knowledge effecting significantly $(p=0.012 ; P R=6.000)$. Female adolescent who has better knowledge would be more ready to face menarche. This study suggested to maximize the role of school and student parents' association to improve reproductive health knowledge program.
\end{abstract}

Keywords: female student, menarche, readiness

\begin{abstract}
ABSTRAK
Remaja putri yang telah memasuki masa puber akan mengalami menarche. Di Indonesia, usia menarche mengalami penurunan dalam beberapa tahun terakhir. Penurunan usia menarche harus diimbangi dengan kesiapan pada remaja putri pra-pubertas, baik secara fisik maupun secara mental. Saat ini banyak remaja putri yang tidak siap menarche. Ketidaksiapan menarche akan berdampak pada buruknya perilaku vulva hygiene dan berisiko terjangkit penyakit menular seksual. Surabaya merupakan salah satu kota dengan jumlah remaja terbanyak di Provinsi Jawa Timur. SDN Pacarkembang 1/192, Kecamatan Tambaksari menyumbang jumlah remaja putri pra-pubertas terbanyak di Kota Surabaya. Penelitian ini bertujuan untuk menganalisis faktor yang berpengaruh terhadap kesiapan menarche pada remaja putri pra-pubertas. Faktor yang diteliti diantaranya pola asuh orang tua, pengetahuan dan jumlah sumber informasi. Penelitian ini merupakan penelitian analitik dengan metode observasional. Desain penelitian yang digunakan adalah cross sectional. Populasi dalam penelitian ini adalah siswi sekolah dasar kelas IV dan $\mathrm{V}$ dengan sampel sebanyak 55 responden. Sampel diperoleh dengan teknik simple random sampling. Data dianalisis menggunakan regresi logistik dengan $\alpha=0,05$. Hasil penelitian menunjukkan bahwa variabel pengetahuan berpengaruh secara signifikan terhadap kesiapan menarche $(\mathrm{p}=0,012 ; \mathrm{PR}=6,000)$. Remaja putri yang memiliki pengetahuan baik berpeluang lebih siap dalam menghadapi menarche. Berdasarkan hasil penelitian, disarankan untuk memaksimalkan peran sekolah dan POM (Persatuan Orang Tua Murid) dalam program peningkatan pengetahuan kesehatan reproduksi.
\end{abstract}

Kata kunci: kesiapan, menarche, siswi 


\section{PENDAHULUAN}

Remaja sebagai aset masa depan bangsa harus dipersiapkan dalam berbagai aspek. Peningkatan kualitas remaja dari segi pendidikan, kesehatan maupun keterlibatan secara ekonomi harus dilakukan sejak dini (BPS Jawa Timur, 2013). Berdasarkan Keputusan Menteri Kesehatan Republik Indonesia Nomor HK.02.02/ MENKES/52/2015 tentang Rencana Strategis Kementerian Kesehatan Tahun 2015-2019, salah satu sasaran strategis yang akan dicapai Kementerian Kesehatan adalah pembinaan ketahanan remaja. Indikator keberhasilan diukur dari peningkatan persentase pengetahuan dan pemahaman remaja tentang kesehatan reproduksi sebesar $75 \%$.

Masa remaja akan dihadapkan dengan kematangan seksual yang disebut dengan fase pubertas. Remaja akan menghadapi perubahan baru dalam hidupnya. Hal ini membutuhkan penyesuaian secara mental (Marheni, 2004). Perubahan bentuk tubuh dan kematangan seksual akan sangat berpengaruh pada kehidupan kejiwaan remaja. Penolakan biasa terjadi pada fase ini (Sulistyoningsih, 2014). Masa puber juga disebut sebagai fase negatif. Fase negatif ini seringkali lebih menonjol pada anak perempuan daripada anak laki-laki (Hurlock, 2007). Perempuan mengalami puber lebih dulu dibanding laki-laki, sehingga mereka membutuhkan perhatian yang lebih terkait kesehatan reproduksi (Gupte, 2004).

Menarche adalah menstruasi pertama yang biasa terjadi pada masa awal remaja di tengah masa pubertas sebelum memasuki masa reproduksi (Proverawati, 2009). Belakangan ini, usia datangnya menstruasi semakin dini di Indonesia. Hasil SDKI 2012 menyatakan bahwa $23 \%$ perempuan usia 12 tahun dan $7 \%$ usia 10-11 tahun sudah mengalami menarche dan $89 \%$ usia menarche remaja Indonesia termasuk dalam rentang usia 12-15 tahun. Persentase ini mengalami kenaikan dari hasil SKKRI tahun 2007.

Kondisi di lapangan menunjukkan bahwa rata-rata remaja putri memperoleh informasi tentang pubertas dari guru $(61 \%)$ dan teman (29\%). Seperempat remaja tidak pernah membicarakan tentang menstruasi sebelum dirinya mengalami menarche. Hal ini diperburuk dengan pengetahuan masa subur wanita sebesar $16 \%$ dan persepsi persetujuan hubungan seksual pranikah sebesar 7\% dengan alasan saling menyukai (SDKI, 2012). Upaya promosi tentang kesehatan reproduksi remaja belum optimal dilakukan di Indonesia. Dari beberapa Laporan Profil Kesehatan kabupaten/kota, didapati perbedaan kelengkapan pelaporan. Kasus remaja belum mendapatkan penanganan yang serius.

Sulistyoningsih (2014) menyatakan bahwa sebanyak 46,7\% remaja putri di Kabupaten Jember belum memiliki kesiapan dalam menghadapi menarche. Sebanyak $70 \%$ siswi mengatakan mereka takut bila dalam waktu dekat akan mengalami menarche, $60 \%$ mereka tidak tahu apa yang akan dilakukan, dan $40 \%$ siswi belum ada persiapan khusus jika akan mengalami menstruasi. Penelitian tersebut sejalan dengan penelitian Fitkarida (2013) yang menunjukkan bahwa $66,7 \%$ remaja putri di Kabupaten Temanggung tidak siap dalam menghadapi menarche.

Pada tahun 2013, Remaja Jawa Timur mencapai 16,13 persen dari total penduduk. Menurut kelompok umur, jumlah remaja terbanyak adalah usia 11-15 tahun (BPS Jawa Timur, 2013). Usia ini merupakan usia sekolah dasar. SDN Pacarkembang 1/192 menyumbang peserta didik terbanyak di Kota Surabaya, yaitu sebesar 951 siswa (Kementerian Pendidikan dan Kebudayaan, 2016).

Berdasarkan hasil studi pendahuluan yang dilakukan di SDN Pacarkembang 1/192, menunjukkan beberapa temuan yaitu $95 \%$ siswi menyatakan takut dan malu apabila nanti dirinya mengalami menarche. Selain itu, hanya $40 \%$ yang mengetahui pemahaman tentang masa pubertas dengan benar. Siswi yang mampu menyebutkan definisi menarche dengan benar hanya sebesar $25 \%$ dan $25 \%$ tidak pernah mendapatkan informasi tentang menstruasi dari orang tua. Siswi kelas IV dan V masih kurang baik dalam penerapan perilaku vulva hygiene. Hasil studi pendahuluan menunjukkan bahwa sebanyak $15 \%$ siswi masih menggunakan celana dalam ketat dan hanya menggantinya satu kali dalam sehari. Sebesar $75 \%$ siswi merasa takut apabila mengalami menstruasi lebih dulu dari teman-temannya. Selain itu, sebagian siswi 
mengatakan bahwa mereka tidak diperbolehkan untuk melakukan kegiatan lari-lari dan olahraga selama menstruasi.

Ketidaksiapan menarche akan berdampak pada buruknya perilaku vulva hygiene remaja putri. Sulistyoningsih (2014) menyatakan sebanyak $50,3 \%$ remaja putri yang tidak siap menarche, memiliki perilaku yang tidak baik dalam perawatan vulva hygienenya. Cheong et al, (2015) menyebutkan bahwa perilaku seksual berisiko, kehamilan tidak diinginkan dan penyakit menular seksual merupakan dampak jangka panjang dari penurunan usia menarche. Kesiapan remaja putri dipengaruhi oleh pola asuh orang tua, tingkat pengetahuan dan jumlah sumber informasi. Oleh karena itu, diperlukan perhatian dan pengasuhan yang optimal dari orang tua untuk meluruskan persepsi anak agar anak tidak takut menarche.

Penelitian ini bertujuan untuk menganalisis faktor yang mempengaruhi kesiapan siswi SDN Pacarkembang 1/192, Kecamatan Tambaksari, Kota Surabaya dalam menghadapi menarche. Pertama, peneliti melakukan identifikasi variabel. Selanjutnya, dilakukan analisis variabel yang berpengaruh.

\section{METODE PENELITIAN}

Jenis penelitian ini merupakan penelitian analitik dengan melakukan analisis data, menjelaskan suatu pengaruh dan menguji berdasarkan teori yang sesuai dari pakar ilmiah atau penelitian terdahulu. Metode penelitian yang digunakan adalah observasional dengan desain penelitian cross sectional.

Responden dalam penelitian ini adalah siswi kelas IV dan V SDN Pacarkembang 1/192 Kecamatan Tambaksari, Kota Surabaya. Waktu penelitian dimulai pada bulan Februari sampai April 2016.

Populasi penelitian adalah siswi kelas IV dan V sebanyak 149 orang yang tercatat dalam data internal jumlah siswi aktif SDN Pacarkembang 1/192, Kecamatan Tambaksari, Kota Surabaya. Responden dipilih secara acak menggunakan teknik simple random sampling. Sampel minimal penelitian didapatkan 44 orang dengan perhitungan rumus Hulley dan Cummings (2007). Sampel yang digunakan dalam penelitian ini sebanyak 55 remaja putri yang belum mengalami menarche.

Pengambilan data primer dilakukan dengan melakukan wawancara dan membagikan kuesioner kepada responden. Data sekunder berupa jumlah siswi SD terbanyak diperoleh dari Dinas Pendidikan Kota Surabaya. Data jumlah remaja terbanyak didapatkan dari Badan Pusat Statistik Kota Surabaya. Data tentang kesehatan reproduksi remaja diperoleh dari SDKI (Survei Demografi dan Kesehatan Indonesia) Remaja tahun 2012.

Teknik pengolahan dan analisis data menggunakan komputer dengan program statistik dan uji Regresi Logistic.

\section{HASIL PENELITIAN}

\section{Distribusi Umur, Tingkat Pengetahuan Jumlah Sumber Informasi Siswi dan Pola Asuh Orang Tua}

Faktor yang mempengaruhi kesiapan siswi SD dalam menghadapi menarche terbagi menjadi dua yaitu internal dan eksternal. Faktor internal yang diteliti adalah umur dan tingkat pengetahuan siswi SD. Sedangkan, jumlah sumber informasi dan pola asuh orang tua merupakan faktor eksternal yang diteliti. Distribusi umur, tingkat pengetahuan dan jumlah sumber informasi siswi SD disajikan dalam Tabel 1.

Umur siswi SD yang tergolong remaja putri pra-pubertas minimal 9 tahun dan maksimal 11 tahun. Tabel 1 menunjukkan bahwa sebagian besar umur siswi adalah 10 tahun $(69,1 \%)$. Pengkategorian umur responden didasarkan pada hasil SDKI Remaja tahun 2012 yang menyebutkan bahwa rata-rata usia menarche remaja putri adalah 12 tahun. Sehingga siswi yang dijadikan sebagai responden penelitian adalah siswi kelas IV dan V dengan umur di bawah 12 tahun yang masuk kategori remaja prapubertas. Mayoritas responden penelitian berada pada usia 10 tahun. Hasil penelitian tersebut sesuai dengan hasil SDKI reproduksi remaja yang menunjukkan bahwa rentang usia 9-11 tahun pada remaja putri merupakan usia prapubertas.

Kategori tingkat pengetahuan siswi terbagi menjadi dua yaitu baik dan kurang. Tabel 1 menunjukkan bahwa mayoritas tingkat 
Tabel 1. Distribusi Umur, Tingkat Pengetahuan, Jumlah Sumber Informasi Siswi dan Pola Asuh Orang Tua

\begin{tabular}{llrr}
\hline & Variabel & Jumlah & Persentase (\%) \\
\hline \multirow{2}{*}{ Umur } & 9 tahun & 2 & 3,6 \\
& 10 tahun & 15 & 69,1 \\
& 11 tahun & 38 & 27,3 \\
\cline { 2 - 4 } & Total & 55 & 100,0 \\
\hline \multirow{2}{*}{ ingkat Pengetahuan } & Baik & 21 & 38,2 \\
& Kurang & 34 & 61,8 \\
\cline { 2 - 4 } & Total & 55 & 100,0 \\
\hline Jumlah Sumber Informasi & 0 sumber informasi & 2 & 3,6 \\
& 1 sumber informasi & 18 & 32,7 \\
& 2 sumber informasi & 27 & 49,1 \\
& 3 sumber informasi & 6 & 10,9 \\
& 4 sumber informasi & 1 & 1,8 \\
& 5 sumber informasi & 1 & 1,8 \\
\cline { 2 - 4 } & Total & 55 & 100,0 \\
\hline Pola Asuh Orang Tua & Otoritatif & 34 & 61,8 \\
& Otoriter & 19 & 34,5 \\
& Permisif & 2 & 3,6 \\
\cline { 2 - 4 } & Total & 55 & 100,0 \\
\hline
\end{tabular}

pengetahuan yang dimiliki siswi SD tergolong kurang $(61,8 \%)$. Pengetahuan yang dibahas pada penelitian ini adalah pemahaman remaja putri pra-pubertas tentang ciri remaja, pengertian pubertas, pengertian menstruasi, menarche dan pentingnya perilaku vulva hygiene. Hasil penelitian menunjukkan sebagian besar remaja putri tidak mengetahui bahwa rentang usia pubertas dimulai dari usia 9 tahun. Selain itu, sebagian besar masih salah dalam menyebutkan perilaku yang berkaitan dengan vulva hygiene. Namun, mayoritas dari mereka mampu menyebutkan definisi menstruasi dan ciri remaja dengan benar.

Pembagian jenis sumber informasi menurut Yusuf (2012) adalah keluarga, sekolah, media cetak (koran/majalah), media elektronik (TV, radio) dan internet. Hasil penelitian pada tabel 1 menunjukkan bahwa sebagian besar siswi mendapatkan 2 sumber informasi seputar informasi dari lingkungannya $(49,1 \%)$. Siswi yang mendapatkan 5 sumber informasi hanya sebesar $1,8 \%$. Berdasarkan hasil penelitian, sumber informasi terbanyak yang diperoleh remaja putri berasal dari keluarga $(92,7 \%)$. Sumber informasi yang berasal dari TV atau radio memiliki pengguna terendah yaitu sebesar $7,2 \%$.
Faktor eksternal lain yang mempengaruhi kesiapan menarche adalah pola asuh orang tua. Pola asuh orang tua terbagi menjadi tiga gaya, diantaranya pola asuh otoritatif, otoriter dan permisif. Tabel 1 menunjukkan bahwa gaya pola asuh otoritatif merupakan gaya pengasuhan terbanyak yang diterapkan orang tua siswi $(61,8 \%)$. Sebagian orang tua menerapkan pola asuh otoriter terhadap anak-anaknya. Namun, orang tua yang menerapkan pengasuhan permisif cenderung sedikit dibandingkan gaya pengasuhan lainnya $(3,6 \%)$.

Distribusi Umur, Pengetahuan, Pola Asuh Orang Tua dan Sumber Informasi terhadap Kesiapan Menarche

Faktor yang diteliti adalah umur, pengetahuan, pola asuh orang tua dan jumlah sumber informasi. Distribusi faktor-faktor tersebut terhadap kesiapan menarche dapat dilihat pada Tabel 2.

Hasil penelitian menunjukkan bahwa sebaran umur terbagi menjadi tiga kelompok yaitu 9, 10 dan 11 tahun. Tabel 2 menunjukkan bahwa semakin tinggi umur responden maka 
Tabel 2. Distribusi Variabel Independen Terhadap Kesiapan Menghadapi Menarche

\begin{tabular}{|c|c|c|c|c|}
\hline \multirow{2}{*}{ Variabel } & \multirow{2}{*}{ Kategori } & \multicolumn{2}{|c|}{ Kesiapan Menarche } & \multirow{2}{*}{ Jumlah } \\
\hline & & Siap & Tidak Siap & \\
\hline \multirow[t]{3}{*}{ Pola Asuh Orang Tua } & Otoritatif & $22(64,7 \%)$ & $12(35,3 \%)$ & $34(100 \%)$ \\
\hline & Otoriter & $11(57,9 \%)$ & $8(42,1 \%)$ & $19(100 \%)$ \\
\hline & Permisif & $2(100,0 \%)$ & $0(0,0 \%)$ & $2(100 \%)$ \\
\hline \multirow[t]{3}{*}{ Umur Remaja Putri } & 9 tahun & $1(50,0 \%)$ & $1(50,0 \%)$ & $2(100 \%)$ \\
\hline & 10 tahun & $24(63,2 \%)$ & $14(36,8 \%)$ & $38(100 \%)$ \\
\hline & 11 tahun & $10(66,7 \%)$ & $5(33,3 \%)$ & $15(100 \%)$ \\
\hline Tingkat Pengetahuan & Kurang & $17(50,0 \%)$ & $17(50,0 \%)$ & $34(100 \%)$ \\
\hline Remaja Putri & Baik & $18(85,7 \%)$ & $3(14,3 \%)$ & $21(100 \%)$ \\
\hline \multirow[t]{6}{*}{ Jumlah Sumber Informasi } & 0 sumber informasi & $1(50,0 \%)$ & $1(50,0 \%)$ & $2(100 \%)$ \\
\hline & 1 sumber informasi & $11(61,1 \%)$ & $7(38,9 \%)$ & $18(100 \%)$ \\
\hline & 2 sumber informasi & $18(66,7 \%)$ & $9(33,3 \%)$ & $27(100 \%)$ \\
\hline & 3 sumber informasi & $4(66,7 \%)$ & $2(33,3 \%)$ & $6(100 \%)$ \\
\hline & 4 sumber informasi & $0(0,0 \%)$ & $1(100,0 \%)$ & $1(100 \%)$ \\
\hline & 5 sumber informasi & $1(100,0 \%)$ & $0(0,0 \%)$ & $1(100 \%)$ \\
\hline
\end{tabular}

tingkat kesiapan dalam menghadapi menarche juga semakin baik. Hal tersebut dapat dilihat pada persentase kenaikan kesiapan menarche dari $50 \%$ menjadi $63,6 \%$ dan meningkat lagi menjadi $66,7 \%$.

Tabel 2 menunjukkan mayoritas responden memiliki tingkat pengetahuan kurang. Tingkat kesiapan tertinggi dimiliki responden yang berada pada tingkat pengetahuan baik, sebesar $85,7 \%$. Tingkat kesiapan terendah dimiliki oleh sebagian responden dengan tingkat pengetahuan kurang, yakni sebesar $50 \%$.

Dari tabel 2 dapat diketahui bahwa tingkat pengetahuan dapat mempengaruhi kesiapan seseorang. Semakin baik tingkat pengetahuan remaja putri pra-pubertas, semakin siap remaja tersebut dalam menghadapi menarche.

Sebagian besar responden hanya mendapatkan 2 sumber informasi tentang menstruasi. Persentase kesiapan cenderung meningkat dari responden yang tidak mendapatkan sumber informasi hingga responden yang memiliki 3 sumber informasi. Namun, tabel 2 menunjukkan semakin banyaknya jumlah sumber informasi tidak menjamin tingginya tingkat kesiapan menarche pada remaja putri pra-pubertas. Hal tersebut dapat dilihat pada tabel bahwa responden yang memiliki 4 sumber informasi dinyatakan tidak siap menghadapi menarche.

Berdasarkan tabel 2, sebagian besar responden dididik dengan pola asuh otoritatif dari orang tuanya. Ketidaksiapan dalam menghadapi menarche tertinggi dimiliki oleh responden yang dididik

secara otoriter dari orang tuanya. Perbedaan gaya pengasuhan yang diterapkan orang tua tidak menjamin adanya perbedaan tingkat kesiapan. Hal ini dapat dilihat pada tabel 2 yang menunjukkan bahwa dengan latar belakang pengasuhan yang berbeda, rata-rata banyak responden yang tergolong siap dibandingkan dengan yang tidak siap.

Uji regresi logistik dilakukan untuk mengetahui faktor yang mempengaruhi kesiapan siswi SDN Pacarkembang 1/192, Kecamatan Tambaksari, Kota Surabaya dalam menghadapi menarche. Hasil uji pengaruh dapat dilihat pada tabel 3.

Tabel 3 menunjukkan bahwa variabel pengetahuan responden dengan tingkat kepercayaan $\alpha=0,05$ memiliki pengaruh signifikan terhadap kesiapan menghadapi menarche. Tingkat pengetahuan dengan nilai signifikan sebesar 0,012 dan rasio prevalensi

Tabel 3. Hasil Uji Regresi Logistik

\begin{tabular}{lcccc}
\hline \multicolumn{1}{c}{ Variabel } & Sig (p) & Exp (B) & SE & Wald \\
\hline Pengetahuan & 0,012 & 6,000 & 0,712 & 6,338 \\
Jumlah & 0,839 & - & - & - \\
informasi & & & & \\
Pola Asuh & 0,287 & - & - & - \\
Konstanta & 0,004 & 0,167 & 0,624 & 8,255 \\
\hline
\end{tabular}


6,000. Dari tabel 3 dapat disimpulkan bahwa tingkat pengetahuan remaja putri pra-pubertas dengan kategori kurang berpeluang 6,000 kali memiliki sikap tidak siap menghadapi menarche dari pada remaja putri pra-pubertas yang memiliki tingkat pengetahuan baik.

\section{PEMBAHASAN}

Umur berkaitan erat dengan potensi reproduksi atau kesuburan, selain itu umur juga menentukan mulai kapan seseorang mengalami suatu perubahan yang ada pada dirinya. Salah satunya adalah fase perubahan di mana dia harus memasuki masa pubertas. Masa puber adalah periode yang unik dan khusus yang ditandai oleh perubahan perkembangan tertentu yang tidak terjadi dalam tahap lain dalam rentang kehidupan. Usia pada masa puber dewasa ini dialami oleh rata-rata perempuan saat berumur 12,5 tahun. Sedangkan pada laki-laki diawali pada umur 14,5 tahun (Hurlock, 2007). Hasil penelitian sejalan dengan teori, menunjukkan bahwa rentang umur remaja putri kelas IV dan V secara keseluruhan di bawah 12,5 tahun yaitu 9, 10 dan 11 tahun belum memasuki masa puber.

Pra-pubertas adalah suatu fase yang dialami remaja sebelum menginjak masa puber. Pada fase ini remaja memiliki potensi untuk timbulnya ciri-ciri seks sekunder. Ciri-ciri seks sekunder telah tampak tetapi organ reproduksi belum sepenuhnya matang (Hurlock, 2007). Fase ini terjadi berbeda-beda antar remaja yaitu dalam rentang 10-12 tahun. Pada fase ini remaja berpeluang untuk mengalami menstruasi pertama (bagi perempuan). Umumnya, anak perempuan mengalami menarche menjelang kelas $6 \mathrm{SD}$. Kecepatan perubahan pubertas bervariasi antara 1,5 hingga 2 tahun untuk mencapai kematangan reproduksi, namun ada juga yang lebih dari itu.

Hasil penelitian menunjukkan bahwa persentase ketidaksiapan dalam menghadapi menarche semakin menurun seiring dengan tingkatan umur. Hal ini menunjukkan bahwa perkembangan fisik sebaiknya diikuti dengan perkembangan psikologis, salah satunya dalam rangka mempersiapkan mental menghadapi masa pubertas.

Suryani dan Widiyasih (2008), menyebutkan bahwa faktor yang mempengaruhi kesiapan menarche adalah umur. Semakin muda umur remaja putri, maka semakin ia belum siap untuk menerima peristiwa haid, sehingga menarche dianggap sebagai gangguan yang mengejutkan. Selain itu menarche yang terjadi sangat awal, dalam artian remaja putri tersebut masih sangat muda umurnya, dan kedisiplinan diri dalam hal kebersihan badan masih kurang, seperti mandi masih harus dipaksakan oleh orang lain, padahal sangat penting menjaga kebersihan saat haid. Sehingga pada akhirnya, menarche dianggap oleh anak sebagai satu beban baru yang tidak menyenangkan.

Pengetahuan adalah hasil yang didapat setelah orang melakukan penginderaan terhadap suatu objek. Pengetahuan atau kognitif merupakan domain yang sangat penting untuk terbentuknya tindakan seseorang (Notoatmodjo, 2011). Hasil penelitian menunjukkan mayoritas remaja putri memiliki tingkat pengetahuan yang kurang. Tingkat kesiapan tertinggi didominasi oleh remaja yang memiliki tingkat pengetahuan baik, sebesar $85,7 \%$. Sebaliknya, tingkat ketidaksiapan terbanyak dimiliki oleh remaja dengan pengetahuan rendah. Notoatmodjo (2011), menyatakan bahwa semakin rendah pengetahuan seseorang maka kecenderungan untuk berperilaku positif juga kurang.

Salah satu aspek penting dari peran manajerial orang tua adalah mengawasi remaja dengan efektif. Pengawasan orang tua tercermin dalam gaya pengasuhan yang diterapkan orang tua (Santrock, 2014). Hasil penelitian menunjukkan bahwa mayoritas orang tua menerapkan pola asuh otoritatif. Perbedaan gaya pengasuhan yang diberikan orang tua akan berdampak pada pembentukan kepribadian anak. Anak yang dididik dengan pola asuh otoritatif akan berpeluang memiliki pribadi yang mudah beradaptasi dengan perubahan yang akan terjadi. Salah satu perubahan tersebut adalah saat remaja putri mengalami menarche. Namun, hasil penelitian menunjukkan bahwa rata-rata kondisi kesiapan yang dimiliki remaja putri pra-pubertas tergolong baik, sehingga perbedaan pola asuh yang diberikan orang tua tidak terlalu memberikan dampak berbeda pada anak. Hal ini disebabkan terdapat faktor lain yang lebih dominan mempengaruhi kesiapan menarche. 
Banyaknya sumber informasi yang diperoleh seseorang akan memberikan berbagai macam pilihan untuk menentukan sikap. Hasil penelitian menunjukkan bahwa ketidaksiapan dalam menghadapi menarche pada responden yang memiliki 1 jenis sumber informasi lebih besar daripada yang memiliki dua atau lebih dari dua sumber informasi. Ayu (2013), menyatakan bahwa akses informasi yang kurang menjadikan remaja tidak siap menghadapi menarche.

Hasil uji regresi logistik menunjukkan bahwa variabel pengetahuan memiliki pengaruh terhadap kesiapan remaja putri dalam menghadapi menarche. Remaja putri yang memiliki pengetahuan kurang berpeluang enam kali tidak siap menarche dari pada siswi yang berpengetahuan baik. Seseorang untuk memberikan respons terhadap suatu hal dipengaruhi oleh stimulus. Berdasarkan teori S-O-R (Stimulus Organisme Respons), kualitas stimulus dapat mempengaruhi perubahan perilaku (Notoatmodjo, 2011). Salah satu penerapan dari teori diatas tercermin dalam kesiapan remaja dalam menghadapi menarche. Kesiapan ditunjukkan dalam bentuk sikap sebagai respons Itertutup dan perilaku sebagai respons terbuka. Faktor yang mempengaruhi kesiapan menghadapi menarche pada remaja putri pra-pubertas sangat beragam, baik faktor dari dalam individu maupun faktor dari luar individu. Faktor internal diantaranya umur individu dan pengetahuan. Notoatmodjo (2011), menjelaskan bahwa tingkah laku manusia merupakan hasil dari pengetahuan. Apabila manusia memiliki pengetahuan kurang, maka dorongan untuk bertingkah laku juga semakin berkurang. Hasil penelitian sesuai dengan teori tersebut, semakin kurang tingkat pengetahuan yang dimiliki seseorang, maka dorongan untuk bersikap siap dalam menghadapi menarche juga kurang. Pengetahuan, pikiran, keyakinan, dan emosi memegang peranan penting untuk menentukan sikap yang utuh.

Beberapa penelitian lain mendukung hasil penelitian yang dilakukan. Leliana (2010), menyebutkan ada hubungan antara pengetahuan dengan kesiapan menarche. Sepakat dengan hal tersebut, Syatriani (2012), menyimpulkan bahwa pengetahuan dan dukungan keluarga berpengaruh terhadap kesiapan menarche. Delvi Novita (2013), menyebutkan hal senada. Menurutnya pengetahuan tumbuh kembang berpengaruh terhadap kesiapan menarche. Hastuti (2014), memperkuat hasil penelitian dengan menyebutkan bahwa pengetahuan tentang menstruasi berpengaruh terhadap kesiapan menarche. Menurut hasil penelitiannya, remaja putri dengan pengetahuan baik memiliki persentase lebih besar $(61,8 \%)$, untuk siap menarche dibanding responden dengan tingkat pengetahuan kurang. Hastuti (2014), menyebutkan bahwa pengetahuan sebagai salah satu faktor predisposisi yang mempengaruhi sikap seseorang. Namun, terdapat penelitian lain yang tidak sejalan, Madina (2011), memberikan argumen bahwa pengetahuan tidak berhubungan dengan kesiapan menarche. Hal ini disebabkan ada faktor lain yaitu tingkat kematangan emosi dan dukungan keluarga.

Pendidikan kesehatan merupakan upaya memberikan penjelasan kepada perorangan, kelompok atau masyarakat untuk menumbuhkan pengertian dan kesadaran mengenai perilaku sehat (Syatriani, 2012). Datangnya menarche dapat menimbulkan reaksi positif maupun negatif. Reaksi negatif yang ditimbulkan apabila remaja putri tidak siap menarche adalah cemas, sedih, bingung, takut, merasa tidak bebas beraktivitas dan menganggap bahwa menarche sebagai beban baru dalam hidupnya. Oleh karena itu diperlukan inovasi promosi kesehatan agar terjadi peningkatan pengetahuan tentang kesehatan reproduksi. Pemahaman yang benar akan mempengaruhi kondisi psikologis remaja putri agar siap menghadapi perubahan baru dalam dirinya.

Hasil analisis regresi menunjukkan bahwa pola asuh orang tua tidak memiliki pengaruh terhadap kesiapan siswi dalam menghadapi menarche. Hasil penelitian tersebut tidak sejalan dengan hasil penelitian yang dilakukan oleh Saputri (2012). Menurutnya, terdapat hubungan yang signifikan antara pola asuh orang tua dengan tingkat kecemasan remaja dalam menghadapi menarche. Salah satu alasan pendukungnya adalah ketika orang tua menerapkan pola asuh permisif, potensi ketidaksiapan dalam menghadapi menarche semakin tinggi. Pandangan serupa juga dikemukakan oleh Dariyo (2004), dan Kopko (2007), bahwa pola asuh permisif bersifat children centered sehingga segala aturan berada di tangan anak 
dan komunikasi verbal yang dilakukan dengan orang tua sangat minim. Dampaknya adalah timbul ketidaksiapan pada anak. Selain itu, pola asuh otoriter juga berpotensi menimbulkan ketidaksiapan menarche. Orang tua dengan gaya otoriter menjalankan pola komunikasi satu arah, sehingga anak tidak diberi kesempatan untuk berpendapat (Surbakti, 2008). Apalagi ketika orang tua merasa tabu untuk membicarakan halhal seputar menstruasi. Saputri (2012), dalam penelitiannya menyebutkan bahwa $80 \%$ subjek penelitiannya yang tidak siap menarche dididik secara otoriter oleh orang tuanya.

Hasil penelitian di lapangan yang dilakukan kurang sependapat dengan analisis dari Saputri (2012). Kenyataan di lapangan menunjukkan sebagian besar orang tua menerapkan pola asuh otoritatif dan sangat sedikit yang menerapkan pola asuh permisif, sehingga terdapat perbedaan pada hasil penelitian. Namun, penelitian Sukesi (2013), mengatakan bahwa pola asuh orang tua yang diterapkan responden penelitiannya sebagian besar demokratis (otoritatif). Dari hasil penelitiannya, pola asuh orang tua tidak berpengaruh terhadap mental emosional anak. Hal ini disebabkan adanya faktor lain yang lebih dominan seperti adanya kemajuan teknologi berupa televisi dan internet.

Berbagai macam gaya pengasuhan akan memberikan pengaruh terhadap perkembangan kepribadian anak. Salah satu perkembangan anak adalah ketika dia memasuki usia pubertas. Namun, hasil penelitian menunjukkan bahwa pola asuh orang tua tidak berpengaruh terhadap kesiapan menghadapi pubertas, yaitu menarche. Hal ini disebabkan karena penilaian pola asuh orang tua dilakukan secara umum untuk menilai berbagai bentuk tindakan orang tua dalam berbagai aktivitas kehidupan. Penilaian pola asuh yang dilakukan tidak hanya terfokus untuk menyiapkan masa pubertas anak.

Hasil penelitian menunjukkan bahwa terjadi kesenjangan antara teori dan fakta. Keluarga seharusnya merupakan wadah pertama dalam memberikan pendidikan kesehatan reproduksi bagi anak (Proverawati, 2009). Hal ini disebabkan waktu terbanyak yang dimiliki remaja putri pra-pubertas sejak dirinya belum menginjak usia pubertas adalah di lingkungan keluarga. Menurut Saputri (2012), seharusnya keluarga menjadi sumber informasi terdekat dan utama bagi perkembangan remaja. Oleh karena itu diperlukan upaya untuk meyakinkan orang tua agar lebih peduli terhadap perkembangan anaknya. Hasil penelitian di lapangan menunjukkan pengetahuan berpengaruh terhadap kesiapan menghadapi menarche. Kualitas sumber informasi yang diberikan akan mempengaruhi pengetahuan anak. Seharusnya orang tua dalam sebuah keluarga berperan penting dalam upaya peningkatan pengetahuan agar anak menjadi siap dalam menghadapi menarche.

Hasil penelitian menunjukkan sebagian besar pola asuh yang diterapkan orang tua adalah otoritatif $(61,8 \%)$. Orang tua dengan gaya pengasuhan otoritatif memiliki karakter ideal menjadi teladan. Gaya otoritatif memiliki mentalitas yang baik dan pemikiran terbuka terhadap ilmu parenting baru. Mentalitas yang mau belajar berubah jika memiliki kekurangan agar dapat menjadi teladan bagi perkembangan anaknya (Santosa, 2015). Pola asuh otoritatif akan mendorong setiap remaja untuk bertumbuh dan berkembang sesuai dengan kapasitas dan kapabilitas mereka (Surbakti, 2008). Orang tua otoritatif mencapai keseimbangan yang baik antara pengendalian dan otonomi. Mereka akan memberi pujian atau hadiah ketika anaknya melakukan hal benar, namun mereka juga akan menghukum ketika anaknya melakukan kesalahan. Mereka memberikan peluang kepada anak-anak dan remaja untuk mengembangkan kemandirian dengan memberikan standar, batasan dan bimbingan yang diperlukan remaja (Santrock, 2014). Orang tua otoritatif memberikan kesempatan bagi anak untuk berpendapat. Orang tua tipe otoritatif mengarahkan tanpa memaksakan kehendak kepada anak. Mereka memberikan penjelasan apabila pendapatnya tidak sesuai dengan kemauan anak. Mereka juga mempunyai pandangan masa depan terhadap anak. Kehangatan dan keterlibatan yang diberikan oleh orang tua yang otoritatif membuat anak lebih bersedia menerima pendidikan orang tua (Santrock, 2014).

Pola asuh otoriter juga diterapkan oleh sebagian orang tua $(34,5 \%)$. Orang tua otoriter kurang sabar dalam memberikan penjelasan mengenai aturan main dan konsekuensi. Orang tua tipe ini lahir dari pola asuh disiplin yang saat 
masih kecil sering menerima hukuman fisik dari orang tua atau gurunya (Santosa, 2015). Banyak aspek yang menyebabkan orang tua menerapkan pola asuh otoriter kepada remajanya. Orang tua yang tidak siap menerima sikap kritis dari anak remajanya sangat berpotensi menerapkan pola asuh otoriter. Mereka menganggap sikap kritis anak merupakan perlawanan atau pembangkangan yang meruntuhkan wibawanya sehingga harus ditumpas (Surbakti, 2008). Remaja yang dibesarkan dengan pola asuh otoriter seringkali cemas terhadap perbandingan sosial, kurang memperlihatkan inisiatif, dan memiliki keterampilan berkomunikasi yang buruk (Santrock, 2014). Penerapan gaya pengasuhan otoriter menghasilkan anak-anak yang tumbuh menjadi orang yang patuh pada peraturan namun berisiko kurang merasa bahagia.

Sebagian kecil orang tua menerapkan pola asuh permisif. Orang tua ini sangat responsif terhadap kebutuhan anak tetapi tidak banyak tuntutan terhadap anak (Santosa, 2015). Dewasa ini, pola asuh permisif cukup banyak diterapkan dalam keluarga. Alasan utamanya adalah orang tua tidak memiliki waktu untuk mengawasi remaja. Mereka memilih kesibukan lain seperti bekerja. Latar belakang pemilihan pola asuh permisif bermacam-macam. Orang tua tidak ingin terganggu dengan kehadiran remaja dalam keluarganya sehingga mereka membebaskan remaja untuk bertindak sesuka hati. Faktor gengsi juga menjadi salah satu sebab penerapan pola asuh pemisif. Apabila orang tua memandang rekan kerja atau tetangganya mampu memfasilitasi remajanya dengan barang mewah, maka dirinya akan merasa gengsi untuk tidak memfasilitasi anaknya dengan hal serupa. Misalnya tren smartphone terbaru. Faktor lain yang mendasari pemilihan pola asuh permisif adalah kurangnya pengetahuan dan pengalaman orang tua, ingin membahagiakan remaja akibat penderitaan masa kecil dan adanya perasaan bersalah (Surbakti, 2008).

Hasil analisis statistik menunjukkan bahwa jumlah sumber informasi tidak berpengaruh terhadap kesiapan siswi sekolah dasar menghadapi menarche $(p=0,751)$. Yusuf (2012) menyatakan faktor yang mempengaruhi menarche diantaranya adalah sumber informasi yang didapat dari keluarga, kelompok teman sebaya dan lingkungan sekolah. Banyaknya sumber informasi yang diperoleh seseorang akan memberikan berbagai macam pilihan untuk menentukan sikap.

Hasil penelitian kurang sesuai dengan teori yang dikemukakan Yusuf (2012). Hal ini disebabkan sumber informasi bukan merupakan faktor yang secara langsung mempengaruhi kesiapan menarche. Banyak tidaknya jumlah informasi tidak menggambarkan kualitas atau isi dari informasi yang diberikan. Kuantitas sumber informasi tidak menjamin tingginya tingkat pengetahuan seseorang. Tingkat pengetahuan seseorang ditentukan oleh kualitas informasi yang diberikan. Selanjutnya, tingkat pengetahuan akan mempengaruhi sikap remaja dalam menghadapi menarche. Selain itu, terdapat beberapa faktor lain yang lebih dominan mempengaruhi menarche diantaranya kelekatan ibu dan anak, dukungan sosial, dukungan keluarga dan kematangan emosi. Berdasarkan penelitian Syatriani (2012), dukungan keluarga berpengaruh terhadap kesiapan menarche. Keluarga merupakan sumber informasi terbesar bagi responden. Sebesar $92,7 \%$ dari responden memberi kepercayaan penuh kepada keluarga dalam hal informasi seputar kesehatan reproduksi. Jayanti dan Purwanti (2011), mendapatkan kesimpulan yang serupa dalam penelitiannya. Proverawati (2009), menyatakan bahwa keluarga berperan penting dalam memberikan pendidikan kesehatan reproduksi pertama bagi remaja, terutama pihak ibu.

Penelitian dari Hidayah (2015) menyebutkan bahwa faktor lain yang mempengaruhi kesiapan menarche adalah kelekatan aman anak dan ibu. Semakin tinggi kelekatan anak dan ibu semakin tinggi tingkat kesiapan anak. Oleh karena itu, diperlukan upaya dari berbagai pihak untuk meyakinkan pentingnya peran, bimbingan dan kontrol orang tua terhadap perkembangan anaknya, sehingga anak tidak mendapatkan informasi yang salah dari sumber informasi lain yang belum tentu diyakini kebenarannya.

\section{SIMPULAN DAN SARAN}

Siswi sekolah dasar yang tergolong remaja putri pra-pubertas sebagian besar tergolong siap menghadapi menarche $(63,6 \%)$. Pola asuh orang 
tua yang diterapkan kepada remaja putri sebagian besar otoritatif $(61,8 \%)$. Umur remaja putri sebagian besar 10 tahun $(69,1 \%)$ dengan tingkat pengetahuan sebagian besar kurang $(61,8 \%)$. Sumber informasi yang dimiliki remaja putri mayoritas sejumlah 2 sumber $(49,1 \%)$. Keluarga merupakan sumber informasi terbanyak yang dimiliki remaja putri (92,7\%). Berdasarkan hasil analisis, faktor yang mempengaruhi kesiapan siswi sekolah dasar dalam menghadapi menarche adalah tingkat pengetahuan siswi $(p=0,012$; $\mathrm{PR}=6,000$ ).

\section{Saran}

Bagi pemerintah khususnya Dinas Pendidikan dan Pemerintah Daerah setempat mengeluarkan kebijakan untuk menyisipkan materi kesehatan reproduksi remaja dalam pelajaran sekolah dasar. Sosialisasi program konseling tentang kesehatan reproduksi remaja dapat disisipkan dalam kelompok ekstrakurikuler yang terdapat di setiap SD. Misalnya, guru memberikan materi keputrian melalui kegiatan ekstrakurikuler. Selain itu, kepala sekolah dapat bekerja sama dengan POM (Persatuan Orang Tua Murid) untuk mempersiapkan mental anak dalam menghadapi masa puber.

Bagi peneliti yang lain sebaiknya dikembangkan kepada faktor-faktor lain yang belum diteliti oleh peneliti. Khususnya diperlukan penelitian tentang budaya, dukungan informasi dari orang tua dan sosio demografi yang mempengaruhi tingkat kesiapan menghadapi menarche pada remaja putri pra-pubertas.

\section{DAFTAR PUSTAKA}

Ayu, S.M. 2013. Hubungan antara Tingkat Pengetahuan dengan Kesiapan Menghadapi Menarche pada Siswi Kelas IV, V dan VI SD Muhammadiyah Kliwonan, Desa Sidorejo, Godean, Sleman. Skripsi. Yogyakarta: FKM Universitas Ahmad Dahlan.

Badan Pusat Statistik (BPS), Badan Kependudukan dan Keluarga Berencana Nasional (BKKBN), Kementerian Kesehatan (Kemenkes), dan ICF International. 2013. Survei Demografi dan Kesehatan Indonesia 2012 Kesehatan
Reproduksi Remaja. Jakarta: BPS, BKKBN, Kemenkes and ICF International.

Badan Pusat Statistik. 2013. Statistik Remaja Jawa Timur 2013. Surabaya: BPS Provinsi Jawa Timur.

Cheong, J.I, et al. 2015. The Effect of Early Menarche on the Sexual Behaviors of Korean Female Adolescent. PubMed Journal Annals of Pediatric Endocrinology Metabolsm 2015; 20: 130-135 ISSN: 2287-1292.

Dariyo, A. 2004. Psikologi Perkembangan Remaja. Bogor: Ghalia Indonesia.

Dinas Pendidikan Kota Surabaya, 2016. Data Pokok Pendidikan. Tersedia di: $<$ http:// profilsekolah.dispendik.surabaya.go.id/ umum/tabel.php $>$ [diakses tanggal 28 November 2015].

Fitkarida, Y. 2013. Perbedaan Tingkat Kesiapan Remaja Putri Usia 10-12 Tahun dalam Menghadapi Menarche Sebelum dan Setelah Diberikan Pendidikan Kesehatan di SD Negeri 1 Sucen Kecamatan Gemawang Kabupaten Temanggung. Karya Tulis Ilmiah. Ungaran: Program Studi Ilmu Keperawatan STIKES Ngudi Waluyo.

Gupte, S. 2004. Panduan Perawatan Anak. Jakarta: Pustaka Populer Obor.

Hastuti, T.P., Widatiningsih, dan Afifah. 2014. Hubungan Tingkat Pengetahuan tentang Menstruasi dengan Kesiapan Menghadapi Menarche pada Siswi Kelas V dan VI di SDN Dangkel, Parakan Temanggung. Jurnal Kebidanan. Vol. 3 No. 7 Oktober 2014. ISSN. 2008-7669.

Hidayah, N. 2015. Hubungan antara Kelekatan Aman terhadap Ibu dengan Kesiapan Remaja Putri Pra-Pubertas Menghadapi Menstruasi Pertama (Menarche). Skripsi. Yogyakarta: Fakultas Sosial dan Humaniora UIN Sunan Kalijaga.

Hulley, S.B., Cummings S.R., Browner W.S., Grady D.G. dan Newman T.B., 2007. Designing Clinical Reseach. $3^{\text {rd }}$ edition. Philadelphia USA: Lipincott Williams \& Wilkins.

Hurlock, E.B., 2007. Psikologi Perkembangan: Suatu Pendekatan Sepanjang Rentang Kehidupan. Jakarta: Erlangga.

Jayanti, F., Purwanti, 2011. Deskripsi FaktorFaktor yang Memengaruhi Kesiapan Anak 
dalam Menghadapi Menarche di SD Negeri 1 Kretek Kecamatan Paguyangan Kabupaten Brebes Tahun 2011. Jurnal Ilmiah Kebidanan, Vol. 3, No. 1 Edisi Juni 2012. Purwokerto: Akademi Kebidanan YLPP.

Kementerian Pendidikan dan Kebudayaan. 2015. Data Jumlah SD di Indonesia. Tersedia di: <http://dapo.dikdas.kemdikbud.go.id/ $\mathrm{rpt} / \mathrm{w} / 056020>$ [diakses tanggal 5 Desember 2015].

Kopko, K. 2007. Parenting Style and Adolescent. Cornel University. Available Online: $<$ http. www.parenting.cit.cornell.edu> [diakses tanggal 10 Mei 2016].

Laila, N. 2011. Buku Pintar Menstruasi: Solusi Mengatasi Segala Keluhannnya. Yogyakarta: Buku Biru

Leliana. 2010. Hubungan Pengetahuan Remaja Putri terhadap Kesiapan dalam Menghadapi Menarche di SD Al-Azhar Medan. Karya Tulis Ilmiah. Medan: Fakultas Keperawatan USU.

Madina, G.N. 2011. Hubungan Pengetahuan Remaja Putri Kelas III-V terhadap Kesiapan dalam Menghadapi Menarche di SD Negeri Mulyorejo 1-237 Surabaya. Skripsi. Surabaya: FKM Universitas Airlangga.

Marheni, A. 2004. Tumbuh Kembang Remaja dan Permasalahannya. Jakarta: Sagung Seto.

Notoatmodjo, S. 2011. Kesehatan Masyarakat: Ilmu dan Seni. Jakarta: Rineka Cipta.

Novita, D. 2013. Hubungan Pengetahuan tentang Tumbuh Kembang Anak dengan Kesiapan Menghadapi Menarche pada Siswi Kelas V dan VIdi SD GMIM Tumaluntung Minahasa Selatan. Skripsi. Manado: Universitas Sam Ratulangi.

Proverawati, A. 2009. Menarche, Menstruasi Pertama Penuh Makna. Yogyakarta: Nuha Medika.
Santosa, E.H. 2015. Raising Children in Digital Era: Pola Asuh Efektif untuk Anak di Era Digital. Jakarta: PT Elex Media Komputindo.

Santrock, J.W. 2014. Adolescence. $11^{\text {th }}$ ed. Dallas: McGraw-Hill Companies, Inc.

Saputri, S. A. 2012. Hubungan Pola Asuh Orang Tua dengan Tingkat Kecemasan pada Remaja dalam Menghadapi Menarche di SD Negeri Nayu 77 Surakarta. Karya Tulis Ilmiah. Solo: UNS.

Sukesi, 2013. Hubungan antara Pola Asuh dengan Perkembangan Mental Emosional Anak Usia Prasekolah (5-6 Tahun) di TK Al Hikmah Mojo Surabaya. Thesis. Surabaya: FKM Universitas Airlangga.

Sulistioningsih, E. 2014. Hubungan Kesiapan Menghadapi Menarche dengan Perilaku Vulva Hygiene Remaja Putri di Sekolah Dasar Negeri (SDN) Kebonsari 04 Kecamatan Sumbersari Kabupaten Jember. Skripsi. Jember: Program Studi Ilmu Keperawatan Universitas Jember.

Suryani E., Widyasih, H. 2008. Psikologi Ibu dan Anak. Jakarta: Fitramaya.

Surbakti, Eb. 2008. Kenalilah Anak Remaja Ada. Jakarta: PT. Elex Media Komputindo.

SusantiA. V. 2012. Faktor Risiko Kejadian Menarche Dini pada Remaja di SMP 30 Semarang. Skripsi. Semarang: Universitas Diponegoro.

Syatriani, 2012. Hubungan Pengetahuan dan Dukungan Keluarga dengan Kesiapan Remaja Putri Usia Pubertas dalam Menghadapi Menarche di SMPN 2 Tellu Siatting Kab. Bone. Jurnal Ilmiah Kebidanan. Vol. 1 No. 3. ISSN: 2302-1721.

Yusuf, S. 2012. Psikologi Perkembangan Anak dan Remaja. Bandung: PT Remaja Rosdakarya. 